\title{
PEMANFAATAN LINGKUNGAN SEBAGAI SUMBER BELAJAR DI MIMPUNDUNGREJO TAHUN PELAJARAN 2019/2020
}

\author{
Umi Nur Afifah Rahmawati \\ BA Aisyiyah Pundungrejo \\ E-mail: uminurafifah21@gmail.com
}

\begin{abstract}
The purpose of this research are: 1) To find out how to use the natural environment as a learning resource for natural science subjects (IPA) in the matter of caring for living things; 2) To find out the supporting and inhibiting factors in the use of the natural environment as a learning resource for natural science (IPA) subjects in the matter of caring for class IV living things at MI Muhammadiyah Pundungrejo Tawangsari Sukoharjo for the 2019/2020 Academic Year. This research uses a descriptive qualitative approach. When the research was conducted from January to June 2020. The subjects of this study were science subject teachers in grade IV, while for informants, namely the principal, teachers of other subjects and some fourth grade students. The data were collected by means of observation, interviews and documentation. The validity of the data used by triangulation of sources and triangulation of methods. The data analysis technique used is an interactive analysis model. The results showed that the use of the environment as a learning resource could give students the widest possible opportunity to explore information through direct discoveries and experiences, and learning became more interesting and fun. There are three stages in preparing for learning through the use of the environment, namely: the teaching preparation stage, the learning implementation stage and the evaluation stage. Supporting factors in the use of the environment as a learning resource include, the natural environment is more contextual, students are more enthusiastic and interested, and students are easier to master the learning material. The inhibiting factor is the changing weather and student conditioning.
\end{abstract}

Keywords: Learning Resources; Natural Science Learning; Utilization of the Natural Environment

Abstrak Tujuan dalam penelitian ini adalah : 1) Untuk mengetahui bagaimana pemanfaatan lingkungan alam sebagai sumber belajar mata pelajaran ilmu pengetahuan alam (IPA) pada materi peduli terhadap makhluk hidup; 2) Untuk mengetahui faktor-faktor pendukung dan penghambat dalam pemanfaatan lingkungan alam sebagai sumber belajar mata pelajaran ilmu pengetahuan alam (IPA) pada materi peduli terhadap makhluk hidup kelas IV di MI Muhammadiyah Pundungrejo Tawangsari Sukoharjo Tahun Pelajaran 2019/2020. Penelitian ini menggunakan pendekatan kualitatif deskriptif. Waktu penelitian dilakukan pada bulan Januari sampai Juni 2020. Subjek penelitian ini guru mata pelajaran IPA di kelas IV, sedangkan untuk informan yaitu Kepala Sekolah, Guru mata pelajaran lain dan sebagian siswa kelas IV. Pengumpulan data dilakukan dengan metode observasi, wawancara, dan dokumentasi. Keabsahan data digunakan dengan triangulasi sumber dan triangulasi metode. Teknis analisis data yang digunakan adalah model analisis interaktif. Hasil penelitian menunjukkan pemanfaatan lingkungan sebagai sumber belajar dapat memberikan siswa kesempatan siswa seluas-luasnya untuk menggali informasi melalui penemuan dan pengalaman secara langsung, dan pembelajaran pun menjadi lebih menarik dan menyenangkan. Terdapat tiga tahap dalam mempersiapkan pembelajaran melalui pemanfaatan lingkunagan, yaitu: tahap persiapan mengajar, tahap pelaksanaan pembelajaran dan tahap 
evaluasi. Faktor pendukung dalam pemanfaatan lingkungan sebagai sumber belajar diantaranya, lingkungan alam lebih kontekstual, siswa lebih antusias dan tertarik, dan siswa lebih mudah untuk menguasai materi pembelajaran. Faktor penghambatnya adalah cuaca yang berubah-ubah dan pengkondisian siswa.

Kata Kunci: Pembelajaran IPA; Pemanfaatan Lingkungan Alam; Sumber Belajar

\section{PENDAHULUAN}

Pembelajaran adalah serangkaian kegiatan yang melibatkan informasi dan lingkungan yang disusun secara terencana untuk memudahkan siswa dalam belajar. Lingkungan yang dimaksud tidak hanya berupa tempat ketika pembelajaran itu berlangsung, tetapi juga metode, media, dan peralatan yang diperlukan untuk menyampaikan informasi. Pembelajaran juga merupakan upaya yang dilakukan pendidik untuk membantu siswa agar dapat menerima pengetahuan yang diberikan dan membantu memudahkan siswa dalam mencapai tujuan pembelajaran (Suprihatiningrum,2017:75).

Pembelajaran secara sederhana dapat diartikan sebagai sebuah usaha mempengaruhi emosi, intelektual, dan spiritual seseorang agar mau belajar dengan kehendaknya sendiri (Fathurrohman \& Sulistyorini,2012:6). Melalui pembelajaran akan terjadi proses pengembangan moral keagamaan, aktivitas dan kreatifitas peserta didik melalui berbagai interaksi dan pengalaman belajar. Pada prinsipnya pembelajaran tidak sama dengan pengajaran.

Guru merupakan unsur yang paling menunjang keberhasilan siswa dalam proses pembelajaran. Hal ini yang menyebabkan seorang guru harus dapat memperhatikan berbagai aspek-aspek yang terkait didalamnya, seperti halnya siswa atau peserta didik. Guru harus bisa memahami kemampuan siswa dalam menangkap setiap materi pelajaran yang disamapaikan. Karena cara siswa dalam menangkap setiap pelajaran berbeda-beda. Sehingga, guru diharapkan dapat meciptakan cara menyampaikan pembelajaran yang berdeda dengan yang lainnya supaya siswa tertarik untuk mengikuti pembelajaran.

Pada tingkat sekolah dasar terdapat beberapa mata pelajaran, salah satunya yaitu Ilmu Pengetahuan Alam, yang sering disebut juga dengan istilah pendidikan sains, yang kemudian disingkat menjadi IPA. Merupakan salah satu mata pelajaran pokok dalam kurikulum pendidikan di Indonesia, termasuk pada jenjang sekolah dasar. Mata pelajaran IPA merupakan mata pelajaran yang selama ini dianggap sulit oleh sebagian besar peserta didik, mulai dari jenjang sekolah dasar sampai sekolah menengah. Anggapan sebagian besar peserta didik yang 
menyatakan bahwa pelajaran IPA ini sulit adalah benar terbukti dari hasil perolehan ujian akhir sekolah (UAS) yang dilaporkan oleh Depdiknas masih sangat jauh dari standar yang diharaplan (Susanto, 2013:165).

Salah satu masalah yang dihadapi dunia pendidikan saat ini adalah masalah lemahnya pelaksanaan proses pembelajaran yang diterapkan para guru di sekolah. Proses pembelajaran yang terjadi selama ini kurang mampu mengembangkan kemampuan berpikir peserta didik. Pelaksanaan proses pembelajaran yang berlangsung di kelas hanya diarahkan pada kemampuan siswa untuk menghafal informasi, otak siswa dipaksa hanya untuk mengingat dan menimbun berbagai informasi tanpa dituntut untuk memahami informasi yang diperoleh untuk menghubungkan dengan situasi dalam kehidupan sehari-hari. Kondisi ini juga menimpa pada pembelajaran IPA, yang memperlihatkan bahwa selama ini proses pembelajaran sains di sekolah dasar masih banyak yang dilaksanakan secara konvensional. Para guru belum sepenuhnya melaksanakan pembelajaran secara aktif dan kreatif dalam melibatkan siswa serta belum menggunakan berbagai pendekatan atau strategi pembelajaran yang bervariasi berdasarkan karakter materi pembelajaran (Susanto, 2013:165-166).

Menurut Piaget dalam Susanto (2013:170) anak usia sekolah dasar yang berkisar antara 6 atau 7 tahun sampai 11 atau 12 tahun masuk dalam kategori fase operasional konkret. Fase yang menunjukkan adanya sikap keingintahuannya cukup tinggi untuk mengenali lingkungannya. Dalam kaitannya dengan tujuan pendidikan IPA, maka pada anak sekolah dasar siswa harus diberikan pengalaman serta kesempatan untuk mengembangkan kemampuan berpikir dan bersikap terhadap alam, sehingga dapat mengetahui rahasia dan gejala-gejala alam.

Pendekatan pembelajaran IPA selama ini masih menekankan pada konsep-konsep yang terdapat di dalam buku (tekstual) dan belum memanfaatkan pendekatan kontekstual lingkungan dalam pembelajaran secara maksimal sedangkan pembelajaran IPA sendiri menuntut peserta didik agar dapat aktif dalam proses pembelajarannya dan bukan hanya duduk serta membaca buku saja. Guru seharusnya menggunakan beragam percobaan atau eksperimen untuk memperjelas materi yang diajarkan sehingga materi dapat dengan mudah diterima oleh peserta didik selain itu dengan melakukan percobaan atau eksperimen guru dapat mengajak siswa untuk berinteraksi langsung dengan lingkungan belajar siswa yang sesuai dengan materi yang diajarkan. Dengan begitu siswa akan lebih merespon dan terjadi timbal balik antara guru dengan peserta didik dan tujuan pembelajaran akan tercapai. 
Lingkungan merupakan sumber pelajaran yang sangat kaya sesuai dengan tuntutan kurikulum. Ada dua bentuk lingkungan belajar, yakni pertama lingkungan atau tempat yang sengaja didesain untuk belajar siswa seperti laboratorium, perpustakaan, ruang internet dan lain sebagainya. Lingkungan semacam ini dikenal dengan lingkungan by disign. Kedua, lingkungan yang tidak didesain untuk proses pembelajaran akan tetapi keberadaannya dapat dimanfaatkan, misalnya halaman sekolah, taman sekolah, kantin, kamar mandi, dan lain sebagainya. Lingkungan yang demikian dikenal dengan lingkungan yang bersifat by utilization. Kedua bentuk lingkungan ini dapat dimanfaatkan oleh setiap guru karena memang selain memiliki informasi yang sangat kaya untuk mempelajari materi pelajaran, juga dapat secara langsung dijadikan tempat belajar setiap siswa. Senada dengan hal tersebut, di dalam Al Quran Allah SWT menjelaskan tentang lingkungan dalam Surah Yunus 101, yang artinya "Perhatikanlah apa yang ada di langit dan di bumi! "Tidaklah bermanfaat tanda kekuasaan Allah dan Rasul-rasul yang memberi peringatan bagi orang-orang yang tidak beriman" (QS. Yunus: 101).

Dari ayat di atas dapat diambil kesimpulan bahwa maksud dari pada lingkungan dalam ayat tersebut adalah lingkungan sebagai sumber belajar. Segala sesuatu yang Allah ciptakan tentunya memiliki rahasia serta hikmah yang akan berguna bagi manusia yang berfikir.

Sumber belajar merupakan alat bantu yang berguna dalam kegiatan belajar mengajar seperti bahan-bahan yang dimanfaatkan dan diperlukan dalam proses pembelajaran, yang dapat berupa buku teks, media cetak, media elektronik, narasumber, lingkungan sekitar dan sebagainya yang dapat meningkatkan gairah belajar bagi peserta didik (Syaiful, 1997:3). Pendidik seharusnya menggunakan sumber belajar yang bervariasi supaya peserta didik tidak merasa bosan dalam proses pembelajaran sehingga tujuan pembelajaran tercapai, salah satu jenis variasi dalam menggunakan sumber belajar adalah dengan memanfaatkan lingkungan sebagai sumber belajar untuk mengoptimalkan proses pengajaran dan untuk memperkaya bahan dan kegiatan peserta didik di sekolah (Sudjana,1989:217).

Sumber belajar sebenarnya tidak memerlukan hal-hal yang mengeluarkan modal yang banyak untuk digunakan oleh pendidik, akan tetapi seorang pendidik seharusnya dapat memanfaatkan lingkungan sekitar sebagai sumber belajar, karena yang terpenting adalah membuat peserta didik nyaman dan tujuan pembelajaran tercapai. Lingkungan yang dimaksud peneliti adalah lingkungan yang ada di sekitar sekolah.

Dari semua mata pelajaran yang ada di sekolah adalah mata pelajaran Ilmu Pengetahuan 
Alam yang erat kaitannya dengan lingkungan sekitar. IPA merupakan ilmu pengetahuan yang berkaitan erat dengan cara mencari tahu tentang alam secara sistematis, sehingga IPA bukan hanya penguasaan kumpulan pengetahuan yang berupa fakta-fakta, konsep-konsep, atau prinsip-prinsip saja, tetapi merupakan suatu proses penemuan. Proses pembelajaran IPA menekankan pada pemberian pengalaman secara langsung untuk mengembangkan kompetensi siswa agar menjelajahi dan memahami alam secara ilmiah (Fatoni, 2012:22). Lebih lanjut dinyatakan pada hakikatnya IPA dapat dipandang sebagai proses yaitu dari upaya manusia untuk memahami gejala alam dengan tata cara yang sifatnya analitis, cermat, lengkap, serta menghubungkan gejala alam satu dengan yang lainnya, sehingga keseluruhannya membentuk suatu sudut pandang yang baru tentang obyek yang diamati. IPA dapat dipandang sebagai produk yaitu dari upaya manusia untuk memahami gejala alam, produk ini berupa prinsip, teori, hukum, konsep maupun fakta yang semuanya itu ditunjukkan untuk menjelaskan berbagai gejala alam. IPA dipandang sebagai faktor yang mengubah sikap dan pandangan manusia terhadap alam semesta yaitu dari sudut pandang mitologis menjadi sikap ilmiah. Tersedianya sumber belajar di lingkungan sekolah, memungkinkan siswa untuk menggali lebih dalam sumber daya yang terdapat di daerahya. Siswa dapat memahami potensi dan sumber daya yang tersedia di daerah sekitarnya. Selain itu, metode ini dapat membantu siswa dalam rangka menyatukan siswa dengan lingkungan sekitar. Siswa dapat lebih peka untuk melestarikan lingkungan sekitarnya. Metode ini juga dapat membantu siswa lebih dekat mengenal lingkungan dan warga sekitar, sehingga memudahkan siswa bersosialisasi dengan baik terhadap setiap orang yang ditemuinya.

IPA tidak dapat dipelajari tanpa mempraktikannya, pemahaman dapat dicapai apabila siswa berperan aktif dalam belajar. Kondisi tersebut sesuai untuk siswa SD/MI. Perkembangan intelektual anak usia SD/MI adalah termasuk katagori operasional konkrit, maka dalam belajarnya sangat membutuhkan pengalaman konkrit. Di samping itu sesuai dengan karakteristik pembelajaran IPA di SD/MI yaitu lebih menekankan pada proses, maka dalam kegiatan pembelajaran hendaknya dapat memberikan pengalaman nyata kepada siswa. Siswa aktif melakukan eksplorasi, percobaan, pengujian, diskusi atau kegiatan lain yang menekankan siswa aktif dalam belajar dengan memanfaatkan lingkungan sekitar.

Pemanfaatan lingkungan sekitar sebagai sumber belajar memang tidak hanya dilakukan di MI Muhammadiyah Pundungrejo. Akan tetapi menurut penulis, pemanfaatan lingkungan 
yang dilakukan di MI Muhammadiyah Pundungrejo terasa berbeda dikarenakan suasana lingkungan yang berada di pedesaan dan dikelilingi oleh perkebunan dan pepohonan yang menambah daya tarik bagi siswa untuk berlangsungnya pembelajaran yang menyenangkan.

Berdasarkan hasil observasi dan wawancara yang dilakukan, peneliti menemukan contoh pembelajaran IPA yang memanfaatkan lingkungan sekitar sebagai sumber belajar. Wali kelas Sugiarto S.Pd selaku guru mata pelajaran IPA di kelas IV menjelaskan materi tumbuhan dan fungsinya yang tidak hanya ceramah di dalam kelas, akan tetapi dengan mengajak peserta didik keluar mengamati tumbuhan langsung seperti : pohon pisang, padi, dan pohon singkong yang ada di lingkungan sekolah. Peserta didik merasa senang dan antisius dalam mengikuti pembelajaran IPA. Berdasarkan latar belakang masalah yang telah dijelaskan di atas, peneliti tertarik untuk melakukan penelitian dengan judul skripsi "Pemanfaatan Llingkungan Sebagai Sumber Belajar Mata Pelajaran Ilmu Pengetahuan Alam (IPA) Kelas IV Di MI Muhammadiyah Pundungrejo, Tawangsari, Sukoharjo Tahun Pelajaran 2019/2020".

\section{METODE PENELITIAN}

Metode dalam penelitian inia adalah kualitatif dengan pendekatan diskriptif. Penelitian kualitatif adalah prosedur penelitian yang menghasilkan data diskriptif berupa kata-kata tertulis atau lisan dari orang-orang dan perilaku yang dapat diamati.Subjek penelitian ini adalah narasumber utama yang memberikan informasi atau data-data yang terkait dengan penelitian dan dibutuhkan oleh peneliti. Dalam penelitian ini subjek yang diambil adalah guru mata pelajaran IPA kelas IV di MI Muhammadiyah Pundungrejo, Tawangsari, Sukoharjo.Teknik pengumpulan data pada penelitian ini meliputi observasi, wawancara, dan dokumentasi serta dengan membuat catatan lapangan.

\section{HASIL DAN PEMBAHASAN}

Berdasar hasil observasi langsung terkait dengan pemanfaatan lingkungan sebagai sumber belajar mata pelajaran IPA, dan wawancara dengan berbagai pihak yang terkait dengan proses pelaksanaan dan pengumpulan dokumen-dokumen yang mendukung terkait pemanfaatan lingkungan sebagai sumber belajar mata pelajaran IPA di kelas IV khususnya pada materi peduli terhadap makhluk hidup dengan jumlah siswa yang keseluruhannya ada 25 siswa, didapatkan hasil bahwa pemanfaatan lingkungan sebagai sumber belajar pada pembelajaran IPA kelas IV di MI Muhammadiyah Pundungrejo secara umum telah berjalan secara efektif. Hal ini 
ditunjukkan pada saat proses pembelajaran dengan memanfaatkan lingkungan sebagai sumber belajar siswa lebih aktif dan termotivasi dalam mengikuti proses pembelajaran, karena guru telah menciptakan suasana pembelajaran yang aktif dan menyenangkan dengan memanfaatkan lingkungan sebagai sumber belajar yang bisa diaplikasikan atau didemonstrasikan secara langsung di luar kelas. Pemanfaatan lingkungan digunakan dalam pembelajaran dengan tujuan untuk memberikan daya tarik tersendiri bagi siswanya dengan merangsang keingintahuan siswa sehingga siswa dapat lebih aktif dalam mengikuti proses pembelajaran. Selain itu, pada saat proses pembelajaran guru juga telah menggunakan berbagai metode, seperti: metode ceramah, metode tanya jawab, dan diskusi. MI Muhammadiyah Pundungrejo untuk pembelajaran tahun 2019/2020 ini sudah menerapkan Kurikulum 2013. Pada proses pembelajaran IPA dengan pemanfaatan lingkungan sebagai sumber belajar di kelas IV terdapat tiga tahapan antara lain:

a. Tahap Persiapan Mengajar

Sebelum proses pembelajaran berlangsung terlebih dahulu guru harus memiliki perencanaan awal kegiatan yang diperlukan untuk kegiatan belajar mengajar agar dapat berjalan efektif dan sesuai dengan tujuan pembelajaran yang akan dicapai. Sehingga pada tahap ini yang perlu dipersiapkan oleh guru yaitu segala sesuatu yang menunjang dalam proses pembelajaran IPA. Tahapantersebut yaitu RPP (Rencana Pelaksanaan Pembelajaran), mempersiapkan materi pelajaran, mempersiapkan media apa yang akan digunakan. Kemudian mempersiapkan sumber belajar dan instrumen evaluasi yang akan digunakan dalam pembelajaran di kelas. Dalam persiapan ini ditanyakan tentang bagaimana persiapan belajar, Yaitu persiapan yang dilakukan Wali kelas yang paling awal adalah mengkondisikan murid terlebih dahulu di dalam kelas, setelah itu menjelaskan sedikit materi apa yang akan dipelajari pada saat itu, setelah itu Wali kelas mengajak murid untuk belajar atau melakukan observasi ke luar kelas. Berdasarkan hasil wawancara dengan subjek dan informan, bahwa persiapan awal yang harus dilakukan oleh guru adalah dengan menyusun RPP sebelum kegiatan belajar mengajar dimulai. Hal ini juga sesuai dengan hasil dokumentasi yang dibuat oleh guru yang berupa RPP. Dimana RPP dibuat sebagai pedoman di dalam pembelajaran. Selain itu dengan menyiapkan RPP, guru dapat menetapkan segala keperluan yang dibutuhkan siswa dalam belajar, baik itu dalam menentukan strategi, metode dan media apa yang akan digunakan sesuai dengan materi yang akan disampaikan. Serta menyiapkan sumber belajar dan instrumen evaluasi yang akan digunakan dalam pembelajaran di kelas sehingga tujuan pembelajaran akan mudah dicapai. 
Selain menyiapkan RPP, dalam pelaksanaan pembelajaran dengan memanfaatkan lingkungan alam sebagai sumber belajar, sebelum pembelajaran dimulai biasanya terlebih dahulu guru menyiapkan media atau apa saja yang akan digunakan dan mengecek kembali kelayakan dari media yang tersedia. Kemudian menyiapkan sumber belajar berupa buku paket IPA kelas IV dan lingkungan alam. Hal ini dilakukan seorang guru agar pelaksanaan pembelajaran dengan memanfaatkan lingkungan alam sebagai sumber belajar dapat berjalan dengan lancar sesuai dengan tujuan pembelajaran

b. Tahap Pelaksanaan Pembelajaran

Pelaksanaan pembelajaran dilaksanakan ketika semua persiapan pembelajaran sudah dipersiapkan dengan sebaik-baiknya. Pelaksanaan pembelajaran merupakan rangkaian kegiatan guru dan siswa atas hubungan timbal balik yang berlangsung untuk mencapai tujuan tertentu. Pada saat pelaksanaan pembelajaran IPA dengan memanfaatkan lingkungan alam di kelas IV, ada beberapa hal yang dilakukan oleh wali kelas antara lain: wali kelas biasanya menyiapkan media berupa tumbuhan asli. Selanjutnya wali kelas memperlihatkan tumbuhan asli kepada siswa di depan kelas dengan menjelaskan materi pembelajaran, lalu Wali kelas mengarahkan perhatian siswa pada sebuah tumbuhan asli sambil mengajukan pertanyaan kepada siswa secara bergantian, kemudian beliau memberikan tugas kepada siswa secara berkelompok ataupun individu. Setelah itu beliau mengajak semua siswa untuk keluar kelas dan belajar di luar kelas memanfaatkan lingkungan alam sebagai sumber belajar. Berdasarkan hasil observasi dalam proses pembelajaran yang berlangsung dengan memanfaatkan lingkungan alam sebagai sumber belajar pada pembelajaran IPA di kelas IV telah mampu memberikan pengaruh yang positif dalam pembelajaran. Dimana dalam proses pembelajaran dengan memanfaatkan lingkungan alam pada pembelajaran IPA guru telah menciptakan suasana pembelajaran yang aktif dan menyenangkan dengan memanfaatkan lingkungan alam yang tersedia serta pada saat itu guru menggunakan lingkungan alam yang bisa diaplikasikan atau didemontrasikan secara langsung kepada siswa.

Lingkungan alam dapat digunakan untuk memberikan gambaran yang nyata kepada siswa tentang pemanfaatan lingkungan alam dapat digunakan sebagai sumber belajar, sehingga siswa tidak hanya membayangkan saja serta mendengarkan penjelasan dari guru saja, namun siswa dapat melihat secara langsung sumber belajar tersebut. Dengan begitu siswa akan lebih tertarik, lebih aktif dan lebih fokus dalam mengikuti proses pembelajaran serta siswa akan lebih mudah 
dalam memahami materi yang telah diajarkan oleh guru. Hal inis esuai dengan penelitian Khanifah dkk (2012) dan Ikhsan dkk (2017) bahwasanya pemanfaatan lingkungan sebagai sumber belajar dapat memberikan siswa kesempatan siswa seluas-luasnya untuk mengali informasi melalui penemuan dan pengalaman secara langsung, dan pembelajaran pun menjadi lebih menarik dan menyenangkan.

c. Tahap Evaluasi

Pada tahap akhir pemanfaatan lingkungan alam sebagai sumber belajar, Wali kelas melakukan evaluasi hasil belajar. Evaluasi pembelajaran merupakan cara yang dilakukan untuk mengetahui tingkat pemahaman siswa terhadap pembelajaran yang telah dilakukan serta dapat digunakan sebagai tolak ukur akan keberhasilan proses belajar mengajar yang dilakukan guru terhadap peserta didik. Berdasarkan hasil observasi, proses evaluasi yang digunakan Wali kelas dalam kegiatan pembelajaran IPA di kelas IV dengan memanfaatkan lingkungan alam sebagai sumber belajar dapat dilihat dari lembar kerja dan kerja kelompok pada saat pemanfaatan lingkungan alam sedang berlangsung di luar kelas. Menurut Darsono dkk (2000) siswa yang belajar dengan mandiri akan lebih cepat paham. Hal ini sesuai berdasaran hasil observasi, bahwasanya siswa lebih mudah memahami pembelajaran IPA melalui pemanfaatan lingkungan.

\section{KESIMPULAN}

Berdasarkan hasil penelitian yang telah dilakukan mengenai pemanfaatan lingkungan alam sebagai sumber belajar pada pembelajaran IPA kelas IV bahwasanya pemanfaatan lingkungan sebagai sumber belajar dapat memberikan siswa kesempatan siswa seluas-luasnya untuk menggali informasi melalui penemuan dan pengalaman secara langsung, dan pembelajaran pun menjadi lebih menarik dan menyenangkan. Terdapat tiga tahap dalam mempersiapkan pembelajaran melalui pemanfaatan lingkungan, yaitu; a) menyusun dan menyiapkan RPP yang berhubungan dengan pemanfaatan lingkungan sebagai sumber belajar; b) menyiapkan media tumbuhan dan sumber belajar yaitu berupa lingkungan alam sekitar sekolahan yang digunakan untuk menyampaikan materi yang akan diajarkan; c) melalukan tes untuk mengukur kemampuan peserta didik dan kerja kelompok saat pemanfaatan lingkungan alam sebagai sumber belajar berlangsung di luar kelas. Faktor pendukung dan faktor penghambat dalam pemanfaatan lingkungan alam sebagai sumber belajar adalah sebagai berikut; a) Faktor pendukungnya antara lain: Lingkungan alam mudah didapat dan mudah 
untuk digunakan, siswa lebih antusias dan tertarik, penguasaan materi oleh guru; b) Faktor penghambat diantaranya: cuaca yang berubah-ubah dan pengkondisian siswa.

\section{DAFTAR RUJUKAN}

Darsono, M. A Sugandhi, Martensi, RK Sutadi \& Nugroho. (2000). Belajar dan pembelajaran. semarang: IKIP Semarang Press.

Fathurrohan, M., Sulistyorini. (2012). Belajar dan pembelajaran. Yogyakarta: Teras.

Ikhsan, A., Sulaiman, S., \& Ruslan, R. (2017). Pemanfaatan lingkungan sekolah sebagai sumber belajar di sd negeri 2 teunom aceh jaya. Jurnal ilmiah mahasiswa pendidikan guru sekolah dasar, 2(1):1-11.

Khanifah, S., Pukan, K. K., \& Sukaesih, S. (2012). Pemanfaatan lingkungan sekolah sebagai sumber belajar untuk meningkatkan hasil belajar siswa. Journal of Biology Education, 1(1): 66-73.

Sudjana, N. (2002). Media pengajaran. Bandung: Sinar Baru Algensindo.

Suprihatiningrum, J. (2017). Strategi pembelajaran teori E aplikasi. Yogyakarta: Ombak.

Susanto, A. (2013). Teori belajar \& pembelajaran di sekolah dasar. Jakarta: Kencana Prenada Media Group. 